\title{
An Analysis Of The Reasons Offered By Post-Graduate Diploma In Education Students In Botswana For Opting For A Teaching Career
}

\author{
Waitshega Tefo Smitta Dibapile, (E-mail: dibapile@mopipi.ub.bw), University of Botswana, Botswana
}

\begin{abstract}
The purpose of this paper was to investigate and analyze the reasons advanced by Post Grade Diploma in Education students (PGDE) for choosing teaching as a career. The subjects of the study were 102 students of which 58 were females and 44 were males. The average age for this group of students was 23. Data were collected using a questionnaire in which a quantitative approach was employed using closed and open-ended questions. The findings of the study revealed that, PGDE students choose the teaching profession mainly for extrinsic reasons such as job security and economic advancement. The paper also indicated that student teachers chose teaching as a career because they wanted to serve the community.
\end{abstract}

\section{INTRODUCTION}

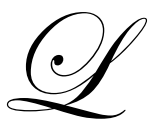

imited research has been undertaken in Botswana with a focus on initial teacher training for graduate students. In line with Vision 2016, Botswana is committed to develop a quality education which is dependent upon the type of teachers that our institutions produce. The essence of this paper is therefore to focus on training of graduate students as teachers.

O'mara (1996) investigated first year students, at Molepolole College of Education on reasons for becoming teachers. He reported that, teaching was chosen by many students with mixed feelings. In his findings some students seemed to be aware of their responsibility as future teachers, but they seem not committed to the teaching profession at all. This raises a question of promoting quality education in Botswana.

The concern for quality education has been expressed in Vision 2016 as follows: "The quality and training of teachers must be improved as soon as possible (p.30). Therefore Botswana Government has given priority to the training of teachers as a means to sustain quality education. However, the factors influencing PGDE students in their choice of teaching have not been investigated. Hence their views regarding the choice of teaching need to be addressed if quality education in Botswana is to be achieved.

Scholars such as Brown (1992) has suggested that, society expects most individuals to have a job and work is perceived as having an impact on an individual's "personal identity and worth". (p. 185). However, there is a difference between having a job and choosing a career. Career choice means that a person has made a decision, and has surveyed the work field. That person has made an assessment regarding work competencies and personal preference.

The individual may have an understanding of what can bring fulfillment and may also have evaluated alternatives, and considered how these alternatives can affect his/her self-concept (Brown 1992). Accordingly reasons for choice can be many and different. They can be economically related, to satisfy an individual's basic needs and they can be for security. Other reasons can be characterized by the feeling that work is a moral obligation 
in the sense that an individual can contribute to and serve society; others may see work as a form of self- expression to benefit others (Brown I992).

Other research evidence also reported similar findings, Joseph and Greene (1986), Serow (1983), (Thomas, 1984 cited in Yong (1995), (Weiner, (1993) cited in Bastick (2000).

The studies of Stiegelbauer (1992) cited in Bastick (2000) explored Canadian students' reasons for entering the teaching profession. They reported that, "the need to make a difference to students and society" was one of the most important reasons that were expressed by the students. Brown (1992) researched Jamaican students' reasons for choosing teaching as a career and also reported altruistic motivations of "wanting to work and be of service" (p.188). Yong (1995) researched students at Brunei, Darussalam, and reported altruistic reasons as a major reason for students entering the teaching profession. From the above research findings, there appears to be general support for the altruistic factor in individuals, across cultures, for choosing teaching as a career.

A number of studies have been carried out in different countries for more than forty years, investigating the motives for students choosing to become teachers (Yong 1995). The factors identified in those studies that have influenced students to make such a choice are reported as falling into three categories: altruistic, intrinsic and extrinsic reasons (Brown, 1992; Chuene, Lubben, and Newson. 1999; Kyriacou and Kobori, 1998).

This paper discusses different research findings with regard to the above mentioned categories of reasons.

\section{ALTRUISTIC REASONS}

These deal with seeing teaching as a socially worthwhile and important job, with a desire to help children succeed, and a desire to help society improve. In America the study of Fox (1961) cited in Joseph and Greene (1986) suggested that the two major factors that influenced students to become teachers were altruistic namely "the desire to work with children and adolescents" (p. 428).

Some intrinsic reasons were also mentioned. These cover aspects of the job itself, such as the activity of teaching children, and an interest in using the subject matter, knowledge and expertise. For example, "Teaching is a noble profession," "I like working with children," and "I have an inborn talent of teaching" are examples of intrinsic reasons for choosing teaching as a career. Research that was conducted in the United Kingdom by Johnston and Mckeown (1999) reported both intrinsic and extrinsic motivations as the main reasons for students entering the teaching profession.

Kyriacou \& Coulthard (2000) and Reid \& Caudwell (1997) have reported that the students made personal choices to train as teachers, and were influenced by their perceptions and the images of teaching as a career. People's perceptions are different, (the PGDE students at the University of Botswana may choose teaching influenced by other factors not just because of the image of the profession).

According to Chuene (1999), "teaching unlike other professions is self recruiting" (p. 23). This is seen as an intrinsic factor, but it has been found that some students, who recruited themselves to train as teachers, may be influenced by other factors like parents, friends, and economic reasons. Flores (2001) suggested that "personal biography and professional identity" (p. 145) can intrinsically influence the students' choices, for example, "feeling like a teacher" and "images of good teaching" and formative experiences that could influence the students to become teachers.

\section{EXTRINSIC REASONS}

These reasons cover the external aspects of the job, which are not inherent in the work itself, such as long holidays, levels of pay and social status. Studies have shown that some individuals are attracted to the teaching profession because of what it offers (Papanastasiou and Papanastasiou, 1997 and 1998). They explored "what made Cyprus University graduates choose Elementary Education major" and reported extrinsic factors of "job benefits" as 
having strongly influenced the students to choose teaching. They also compared Cypriot students with University of Pennsylvanian students in America, on the factors that have influenced them to become teachers. Extrinsic reasons were reported to have an influence on Cypriot students.

The studies mentioned above reported that teachers in Cyprus are well paid when compared to other professions and had good working conditions that could have influenced students to become teachers. The Pennsylvanian students showed that they love teaching children and that working with young children influenced them to choose teaching as a career. Bastick's (2000) Flores's (2001) findings reported that Jamaican and Portuguese students also reported that extrinsic reasons were their drive for entering the teaching profession.

\section{RESEARCH MODEL}

Brown (1992) suggested that the reasons for career choices might be classified in three categories; altruistic, pragmatic and developmental. The model is displayed as follows:

Figure 1: Categories of reasons for career choice. Brown (1992: 186)

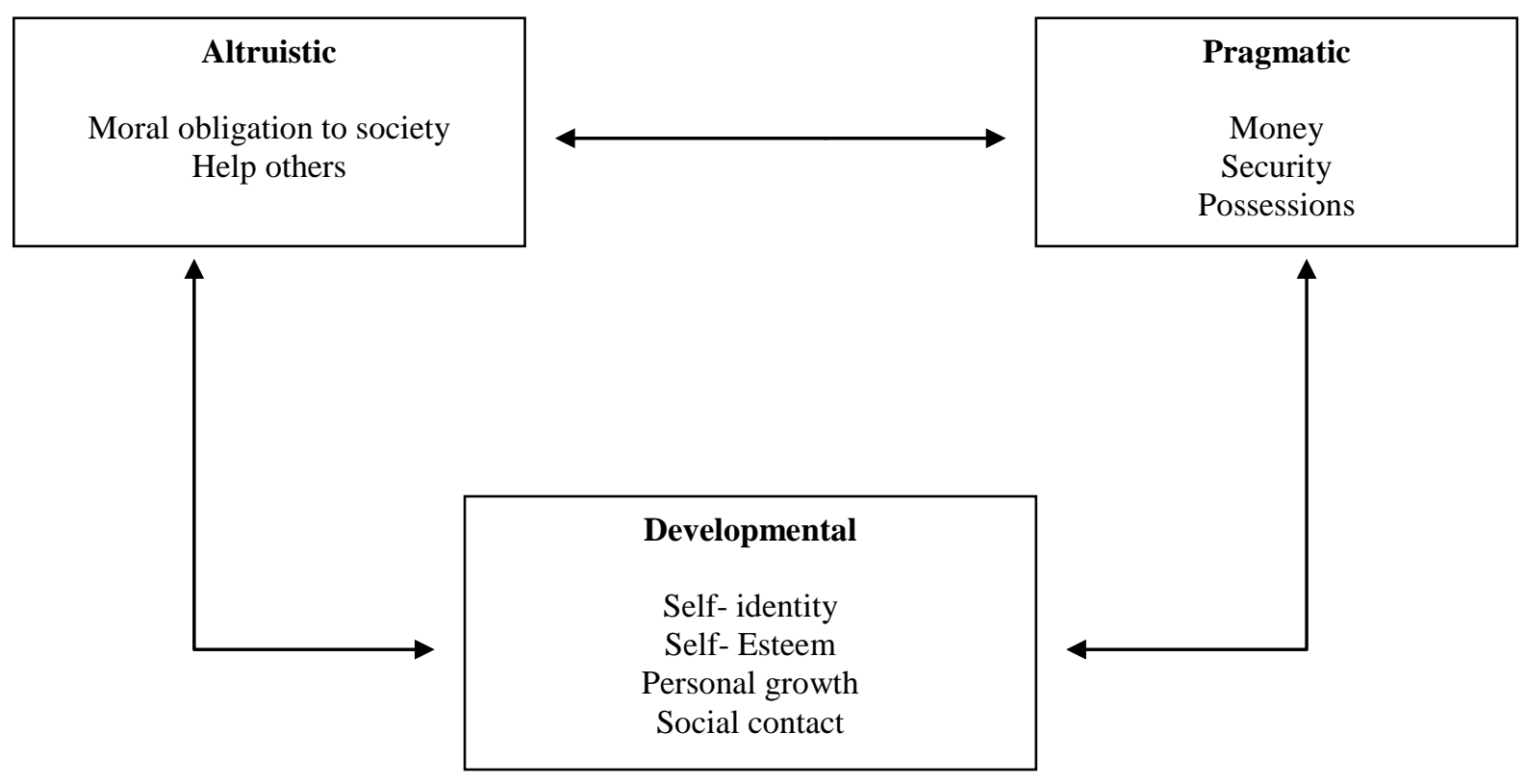

The model shows an interaction between pragmatic, altruistic and developmental reasons of career choice. The individual may fulfill the goals of career choice by contributing to society or becoming economically independent fulfilling one's self-esteem. Brown (1992) suggested that there is a relationship between pragmatic and altruistic reasons. When an individual is motivated from altruistic there is a tendency to consider what is important in terms of satisfying the basic needs. There is a requirement, however, for balance between the two if a person needs to experience personal growth.

\section{STATEMENT OF THE PROBLEM}

The teaching profession in Botswana has suffered from general negative comments. In general teaching has been perceived as a profession which individuals who enter it do not seriously consider it as a 'mission' or preferred 
job, but rather they choose it as the last resort (O'mara, 1996) The National Commission on Education of (1977) has expressed concern in these words

Teaching is regarded as a profession of low status in Botswana and some Batswana enter teaching as a second or third choice or because nothing else is available. For as long as this attitude remains, people of the required quality will not be attracted into teaching (p. 5-6)

The National Commission of Education of (1993), findings expressed the same concern, "low morale and declining status" of the teaching profession is still evident across the country. Therefore if teaching is perceived negatively in Botswana, this could also influence the teacher trainees, they may choose to become teachers but still may take teaching as the last option when they do not get the careers they prefer.

The University of Botswana is the only institute in the country that offers Post- graduate Diploma in Education (PGDE) courses. It is not known why PGDE students chose teaching as a profession. However the main of the PGDE's programme is to train teachers of high quality who would in turn promote quality education. This is in line with the Government Vision 2016 which calls for an educated nation. Therefore, improving quality of education is a top Government priority.

\section{PURPOSE OF THE STUDY}

The aim of this paper was to investigate the reasons offered by Postgraduate Diploma In Education students of the University of Botswana for Choosing teaching as a career. The paper will examine some factors that have influenced student teachers to choose teaching as a profession.

\section{SIGNIFICANCE OF THE STUDY}

The study is a significant to policy makers and teacher educators particularly those who admit students in PGDE programmer. This would be in a better position to admit students who are committed to education and whose aim is to enhance quality education.

\section{METHODOLOGY AND PROCEDURES}

This research study employed a quantitative research methodology in which a questionnaire was used. A research instrument was designed in this study. The study used a questionnaire because it was most appropriate for collecting data and it was easier for the subjects to complete.

The instrument was validated by a panel of experts as most appropriate and feasible for answering research questions. The instrument consisted of two parts - A and B. Each part has its own instructions. The items were ranked ordered to enable respondents to make choices regarding options.

\section{RESEARCH ITEM I}

The study investigated what aspect of teaching the students were interested in, as well as their motivations for choosing teaching as a career. Questions 16- 20 are Likert Type scale items, where the individual checks one of five possible responses to the statements Strongly Agree (SA), Agree (A), neutral (N), Disagree (D), and Strongly Disagree (SD) to the factors that have influenced them to choose teaching as a career. The Likert Type Scale is useful to the researcher as they build on the sensitivity and differentiation of response.

The researcher was aware that quantitative data use more numbers particularly when coding and analyzing them. Therefore the set of response categories, for example, Agree- Strongly Disagree was scored using numbers by the computer. (SPSS programme). The items were then linked with each other. Accordingly the scale attempts to measure one item at a time. The study wanted to measure the students' attitudes in their choice of teaching. 
However, Mertens (1998) argued that instead of using the Likert Scale, follow up interviews could be used to "determine the meanings attached to the numerical ratings" (p. 165).

Gender, age, nationality were also investigated. The contact address of the researcher was included in case the respondents were interested in knowing the result and findings of the study.

\section{SAMPLE}

The study was based on the students taking Postgraduate Diploma in Education at the University of Botswana, Gaborone. The University of Botswana is the only institute on the country that offers the PGDE course. All 315 PGDE students were sent a questionnaire along with a request that they help the researcher. A self- selected sample of 102 returned the questionnaire.

\section{PILOT WORK}

The questionnaire was piloted with five students in the Graduate School of Education of the University of Bristol, Mertens, (1998) has suggested some steps to follow when pilot testing a questionnaire. One of them is the sample selected should be similar to the research population. The similarity between the chosen students for pilot work and the PGDE group in Botswana is that both have chosen teaching as their career. They are able to think about their reasons for choosing teaching. Another reason for piloting is to help the researcher to see how the process of completing a questionnaire works, and to note any "ambiguities" or response options that are not involved in the questionnaire.

Rosier (1997) commented that pretests also act in a way of providing the opportunity to check the respondent's understanding of the meaning of the questionnaire and statements. Babbie (1973) argues that the pilot sample should be chosen in exactly the same fashion as is intended for the final survey. The next best thing was to select students who chose teaching as their profession. Some of the respondents corrected the wording of the questions that they thought might create difficulties in understanding the questionnaire. The researcher made some corrections to help students to understand the questionnaire.

According to Cohen et al. (2000) a pilot has many functions, for example checking the clarity of the questionnaire items, instructions and layout. Therefore the researcher piloted and pre-tested the questionnaire for some reasons as follows: to gain feedback on the type of questions and its format (e.g. for rating scale, multiple choices, open, closed etc). Also to check whether the questionnaire was too long or too short, too easy or too difficult, too engaging, too threatening, too intrusive, too offensive" (Cohen et al. 2000, p. 260).

The PGDE students commented about item no. 7, part $b$ (see questionnaire-for PGDE students) concerning the teachers' accommodation. They responded that, this was not a reason for them. The reason is teachers in Botswana are accommodated differently because they are teachers. Teacher's houses are mostly built within the school premises or very close to the school premises.

\section{DATA COLLECTION}

According to Weinberg (1983) the time that is scheduled for data collection should be related to the people available. However, for the present study the researcher could not find the students in the University as they were out for teaching practice in schools across the country. The headmasters of secondary schools were requested by the researcher through telephone communications to administer the questionnaires to the PGDE students doing teaching practice. The other headmasters collected the questionnaire from the Educational Foundations department and sent them to headmasters in some schools.

Rosier (1997) suggested that at the beginning, the appropriate administrative authorities should be consulted. The letter was written to the head of the Educational Foundations department by the researcher's personal tutor in support of the researcher's own letter requesting them to allow the researcher permission to collect the data. 
The aim and the importance of the survey were stated in the letter. Accordingly the authorities and the respondents were well informed about the relevance and importance of the study. Their cooperation was crucial since value and credibility of surveys depend on the high response rate" (Weiner 1983, p. 158).

\section{DATA ANALYSIS}

This section discusses the analysis of the responses received from the questionnaire. According to Birley and Moreland (1998) coding has been defined as "the process of assigning a symbol as a shorthand way of summarizing a completed questionnaire response”. (p. 158).

Typical numbers and letters are used in coding. The questionnaire was numbered for identification purposes; for example, questions 1-20 were numbered.

The variables of interest from the questionnaire were code each question that was not completed was regarded as missing and was given the number 99. The response for question 2 was categorized into three main reasons of decision making for example, altruistic, intrinsic and extrinsic.

There were two open ended questions; most of the questions were closed questions hence giving the researcher opportunities for minimizing the analysis problems that could be encountered and therefore making the questionnaire to be more reliable. According to Oppenheim (1992) closed questions and checklists usually yield higher frequencies than open-ended questions, particularly with questionnaires. Part A and B for Likes and Dislikes were coded.

\section{DATA PRESENTATION}

The data in the present study were presented in bar charts. The main reason for using bar charts is the data need to be collected and presented in a way that it is understandable as well as interesting to the researcher and other readers Birley and Moreland (1999). The present study analyzed the data and presented it in bar charts and used statistics to describe it. (Birley and Moreland 1999) suggested that the quantitative data could be described using descriptive statistics, for example, pie charts, tables, and graphs.

\section{LIMITATIONS OF METHODOLOGY}

The aim of methodology is to help us to understand, in the broadest possible terms not scientific enquiry but the process itself (Cohen and Manion 1996, p. 39). This paper discusses the limitations in regard to the research design. Questionnaire was used as a method of collecting data.

The questionnaire is a good method in an educational enquiry. Contrary to that, Oppeinhem (1994) and Blaxter (1996) argued that generally low-response rate and resultant biases characterizes the questionnaire. The respondents in a self-administered questionnaire are usually left alone to complete a questionnaire. This writer notes some low responses emerged because the researcher was not available to assist where there might have been some misunderstanding.

Sapsford (1999) expressed a similar view, that the major disadvantage with the questionnaire is there is no one available to assist the respondents to understand what is needed.

There were low responses, as most students could not answer some questions for example, question number. 2 (Part A see questionnaire) there was a lot of missing answers. This shows that the students did not decide to become teachers, as the question asked what motivated them to become teachers. The other limitation of using questionnaire was when the researcher analyzed the questionnaire, some of the personal statements made by the respondents were, "I was forced to do PGDE," and "I was forced into teaching" (Female number 37 aged 26). 
The researcher notes that if students are interviewed, it will be useful to identify students who feel teaching is not their priority. The last question of Part A, the respondents were asked to specify some aspects of the teaching profession they like or disliked. Most of them did not respond to the question, as the researcher could not administer the questionnaire herself. Therefore she had no chance of correcting misunderstanding or as Oppenheim (I 994) stated, nor to explore, or to give explanation or assistance. The study is quantitative in nature, and according to Tuah (1995) quantitative data lack "depth" and the richness of information that can be obtained by a qualitative approach. It is then not possible to include sensitive issues in the questionnaire.

Some respondents were reluctant to answer the open-ended questions, especially question no. 5 part A, which required them to specify other aspects of the teaching practice that they liked or disliked. Also the second question asked them what motivated them to become teachers. The students did not complete such questions and others; it was difficult for the researcher to understand clearly what the respondents meant. It was also time consuming for the researcher to analyze the open-ended questions. During the analyzing of the questionnaire the researcher felt that some of the respondents were not sincere when answering the questions.

Denscombe (1997) similarly commented “...questionnaires offer little opportunity for the researcher to check the truthfulness of the answer by the respondents..." (p. 106) unlike interview methods on which the researcher can rely for the respondent's communications.

\section{DISCUSSION OF THE FINDINGS}

This paper offers summary of the research data; findings of the study, limitations and some recommendations will be explored. The study aimed to investigate and analyze the reasons for Postgraduate Diploma in Education students choosing teaching as a career. The factors that influenced teacher trainees for choosing teaching has been explored and discussed in the research literature.

The study was quantitative in nature. A self-administered questionnaire was offered to all PGDE students. One hundred two Postgraduate Diploma in Education students completed the questionnaire.

This paper reports that extrinsic motives were dominant determinants for trainee teachers' entry to the teaching profession in the University of Botswana. The reason that is frequently mentioned was job security, where the trainees are aware that, after completing their teaching programme they are offered employment. The students are 'pulled' towards teaching by what the job offers rather than the activities of teaching children, often through extrinsic reasons of job security. If people come into teaching for economic reasons it may be important that the teacher training institutions highlight throughout the programme the other major important reason for teaching. For example, encouraging the love of a subject and a desire to share that with young people, or encouraging trainee teachers to see the importance of teaching in molding young people.

Responses like "I wanted some money" (female number 15, aged 29) shows that, the trainees were not interested in teaching itself but what the job offers, that is material benefits, for example job security and salaries. It is with concern that in the present study that most trainees responded highly with extrinsic reasons. They use teaching as a stepping ladder to other professions; there is a need to pay attention to their responses by administrators of the students to the teaching programme.

The Government of Botswana is challenged to improve the incentives for teaching and its low status as reported by the trainees' and individuals who did not decide to teach can be attracted and have a positive attitude towards who are teachers due to the attractiveness of the job. Altruistic reasons also had an impact on the trainees' choices of teaching. There is a need to investigate further by the teacher educators in order to help the students to become aware of reasons of choosing teaching as a career. Most students responded that they wanted to help children, this helping responses needs investigating. A typical response was "I want to mold the youth" but it is not clear what molding the youth may mean to some individuals. 
In contrast, statements like "I want to be a boss in the classroom" causes concern and not all teachers are altruistic, this shows dominance that some teachers may use the classroom setting for their advantage, rather than giving priority to the interest of the children. Kohl (1984) commented that some people teach in order to dominate others. In the Botswana context, particularly in the classroom settings 'banking education" prevails as pointed out by Freire (1972) cited in Tabulawa (1997) (p. 189) the teacher is viewed as the depositor and the students are depositories who must bank the deposited education. Some teachers can enjoy being authoritative, influenced by the didactic classroom practice and "chalk and talk method". The society also has a high respect for teachers in Botswana. They are addressed by titles "Mr., Mrs., and Miss" their first names are not used officially but second names and therefore such respect for individuals who choose teaching because they want to be bosses in the classroom can increase the dominance on the learners. The Government has honored teachers for their service to the society. There is Teachers' Day every year in the first week of May. Yong (1995) commented, "Orientation towards teaching based on the extrinsic or pragmatic reasons alone may not be sufficient to make teachers fully committed to teaching" (p.279).

This paper also found that, the other reasons for the students for choosing teaching were altruistic. The trainee teachers reported that they want to help reduce the shortage of teachers in Botswana because there were many expatriate teachers in the country especially Secondary and Teacher Training Colleges. Serow (1993) argued that altruism is "institutional rather than individualized" and with reference to motives for career choice, altruism is defined as "concern for others at the expense of ones own interest" (p. 198). Therefore some teacher trainees in the present study seem to have made a decision to teach because of their concern for the nation.

Most of the teacher trainees' responses were striking for example "I have chosen a profession that I am stuck in." The trainees had already completed their first degree the author expected them to enjoy the profession they have chosen. Joseph and Greene (1986) commented "teaching may not be a variable career choice for many people who in the era enter teaching" (p. 30).

The model shows an interaction between pragmatic, altruistic and developmental reasons of career choice. The individual may fulfill the goals of career choice by contributing to society or by becoming economically independent fulfilling one's self-esteem. Brown (1992) suggested that there is a relationship between pragmatic and altruistic reasons. When an individual is motivated from altruistic there is a tendency to consider what is important in terms of satisfying the basic needs. There is a requirement, however for balance between the two if a person needs to experience personal growth.

\section{AGE FACTOR}

Most research work reported does not address the age at which individuals have to make decisions to teach. The study of Tudhope (1944), cited in Yong (1995), showed that young people decided to become teachers for extrinsic and altruistic reasons, but they did not specify the age at which the students entered the teaching profession. O'mara (1996) reported age of first year students, ranging from 20-25 years, 87\% were females who have chosen teaching as a career. The age at which individuals choose teaching needs to be investigated because some young adults are still exploring the work field. Those with pre-teaching experience should be considered, because they may remain longer in the teaching profession. This can shed light on the understanding of people's choices whether it is due to economic reasons or the interest in the profession itself, or whether they develop the interest of teaching at an early age.

Past research has not addressed the question of liking or disliking the teaching career. This was noted whilst reviewing the research literature. In Botswana there are limited job markets. Chapman, Synder, and Burchfield (1993) reported that 20\% of Batswana (people of Botswana) are unemployed, and most teachers might find it difficult to find employment offering comparable compensation (p. 304).

Some individuals are attracted to teaching mainly by extrinsic and altruistic reasons. Some people, as Maslow (1968) suggested, may be of "self actualization, for example, self-fulfillment" and realizing one's personal 
potential. Therefore individuals may realize that teaching does not make him /she realizes his/her potential and so they may not feel safe in the job and then as a result dislike it.

Some individuals in the present study may have chosen teaching to perform and fulfill their intrinsic reasons as indicated by the above mentioned research findings.

\section{RECOMMENDATIONS}

This paper suggests some recommendations for teacher educators and policy makers. The Postgraduate Diploma in Education students indicated that they did not decide to teach. Therefore the University of Botswana that offers the PGDE programme can ensure that the students who enroll in BA Humanities + PGDE should have a pre- teaching experience, which can be another requirement. This will help in the sense that, at least those who enroll in the teaching programme may have taught before, and may remain longer in the profession, and be effective in their work, rather than choosing teaching and at the end of the programme students may be uncertain and they do not know if they want to teach.

Teacher educators need to interview the prospective teacher trainees before they are given admission to the teaching profession. The findings of this paper report that the teacher trainees choose teaching because of the extrinsic reasons.

Applicants who show more of the intrinsic and altruistic characteristics may be given priority for admissions. Although Beatrice (1991) argued that it is not easy to discover the motives of teacher training applicants at interviews, as they may give valid reasons for enrolling in the teacher training such as that they love teaching. The researcher notes that by interviewing, motivated candidates can be helpful in enrolling committed teachers but not only those who enroll in the programme for extrinsic reasons only.

From the findings, many teacher trainees do not perceive teaching as a high status profession. The Government needs to improve the status of the teaching profession to gain the respect that it ought to have liked other professions such as nursing, medicine and law. The Department of Teacher Training and Development, Teaching Service Management, Botswana teachers' associations, and District Councils need to improve the welfare of teachers by increasing their salaries and developing the conditions of teaching in general.

The Teaching Service Management and District Councils need to establish Teachers Agencies that could help in employing teachers especially in primary and secondary schools. This will reduce the load of work that the Teaching Service Management now is engaged in. The teacher trainees have also responded that they dislike Teaching Service Management inefficiency in work related matters.

Temporary teachers should be employed only if they have at least a certificate in teaching, rather than employing individuals without proper teaching qualification. Education Centers, as they offer in-service courses and workshops need to have part- time courses for people who are interested in teaching. The teacher educators in Educational Foundations might assign teacher trainees to individual pupils in local schools while on training so they can learn more in practice about behavior and personalities of the learners. Students may visits schools that have students with special needs.

Attention needs to be paid to those teacher trainees who responded that they "dislike disruptive class" (46\%). The educational psychology classes need to discuss more with the trainees about individual differences in behaviors, and also about learners with special needs. Some modules of Special Education may be introduced in the PDGE program. The teacher trainees can also be aware of different behaviors the students display and be in the position to accept and help them. Teacher educators need to be in the position to help and prepare them for being committed to their work when they complete the course. Joseph and Greene (1986) suggested, "Teacher educators must help candidates to understand their reasons for becoming teachers and consider how their motives will affect their career" (p. 32). Particularly, because some of the trainees responded that they dislike lesson plan preparation. These are the students who ought to be helped to understand their reasons for becoming teachers. They will be the 
ones who may go to teach without preparing for the lesson and may become unproductive in their work this needs attention, because the writer once assessed the previous PGDE group in teaching practice and they had difficulty in evaluating the lessons they had taught.

\section{FUTURE RESEARCH}

The paper concludes by suggesting some directions for future research in investigating more about the students' reasons for choosing teaching as a career. The research needs to explore further the reasons for choosing teaching as a career with the teachers who are already teaching in the field. Since little research is carried out into students' reasons for choosing teaching, more research is needed to explore the students' motives with the other six affiliated Teacher Training Colleges, and Bachelor of Education primary and secondary students in the University of Botswana. Comparative studies of both PGDE and B. Ed. students will be useful and also comparative studies with students in other countries in Africa will contribute to improved understanding of the students' reasons for choosing teaching in different countries.

The present study was quantitative; few responses of qualitative data were also used for example, responses like "I like helping students learn". However, a more detailed qualitative approach (interviews) will be useful than quantitative. Most of the trainees did not complete the question "What motivated you to become a teacher"? Other students wrote the word "nothing" whereas if there were interviews, they may have responded more when the researcher was present interviewing them Future research needs to investigate PGDE students' reasons for choosing teaching, as a career is needed. They need to find out about the course schedule because by April the students are busy with the examinations and they are often not available. When they finish their examinations they go for teaching practice across the country.

\section{CONCLUSION}

This paper concludes that the teacher trainees in the University of Botswana have chosen teaching for extrinsic reasons. Also, if students come into teaching for economic reasons it may be important that the teacher training institutions highlight throughout the programme the other major important reasons for teaching. An example is encouraging the love of the subject and a desire to share knowledge with young children. As discussed earlier in this paper, the results showed that most of the teacher trainees did not make an active decision to teach. Most of those who opted to teach did for extrinsic and personal security reasons. These reasons are useful to the policy makers and teacher educators particularly when they admit future students to the PGDE course, because most students responded that they chose teaching because employment is offered after completing the course.

Many were ambivalent about the profession. They were concerned also about the poor reputation of teachers and education but were pleased by the prospect of job security.

\section{REFERENCES}

1. $\quad$ Babbie, E. R. (I 973) Survey Research Methods, Califomia: Wadsworth.

2. Bastick, T. (2000) "Why teacher trainee choose the teaching profession? Comparing trainees in Metropolitan and developing countries", International Review of Education, 46, 3/4 pp. 343-349.

3. Birley, G \& Moreland, N (1999) a practical Guide to Academic Research, London: Kogan Page.

4. Blaxter, L., Hughes. C., \& Tight, M., (1996) How to Research, Buckingham: Open University Press.

5. Botswana, Republic of (1977) Report of the National Commission on Education, (1977) Gaborone: Goverm-nent Printer.

6. Botswana, Republic of (1993) Report of the National Commission on Education (1993) Gaborone: Government Printer.

7. Brown, M. (1992) "Caribbean First- year Teachers ' Reasons for Choosing Teaching as a career", Journal of Education for Teaching, 18, 2 pp. 185-195.

8. Chapman, D., Synder, C.W., \& Burchfield, S.A., (1993) Teacher Incentive in the third World, Teacher and Teacher Education 9,3, pp. 301-316. 
9. Chuene, K., Lubben, F., \& Newson, G., (1999) "The views of pre- service and novice teachers on mathematics teaching in South Africa related to their educational experience", Educational Research, 41, 1 pp. 23-34.

10. Cohen, L \& Manion L (1996) Research Methods in Education: Fourth Edition: London: Routledge.

11. Cohen, L., Manion. L., \& Morrison, K., (2001) Research Methods in Education, London: Routledge.

12. Denscombe, M. (1998): The Good Research Guide for Small Scale Social Research Projects. Buckingham: Open University Press.

13. Flores, M.A. (2001) "Person and context in becoming a new teacher". Journal of Education for Teaching, 27, 2 pp. 135-148.

14. Johnston, J. Mckeown, \& MckEwen, A. (1999) "Choosing Primary Teaching as a Career", Journal of Teaching for Education, 25, 1 pp, 55-64.

15. Joseph, P. B. \& Greene, N. (1986) "Perspectives on Reasons for Becoming Teachers ", Journal of Teacher Education, 3 7, 36 pp. 28-32

16. Kohl, H. (1984) Growing Minds, On Becoming a Teacher, New York: Harper \& Row Vision for Botswana (1997).

17. Kyriacou, C. \& Kobori, M. (1998) "Motivation to Learn and Teach English in Slovenia", Educational Studies, 24, 3, pp.345-351.

18. Kyriacou, C. \& Coulthard, M. (2000) "Undergraduates Views of Teaching as a Career Choice", Journal of education for Teaching, 26, 2 pp. 1 17-126.

19. Mertens, D.M (1995) Research Methods in Education and Psychology: Integrating Diversity with Quantitative and Qualitative approaches, London: Sage.

20. O'mara (1996) "Students' Reasons for Becoming Teachers: The Case of First Year Students at Molepolole College of Education", in Charakupa, R (Eds) Pathways into the 21" Century: New Directions in Teacher Education, Gaborone, Heinemann Educational Publishers.

21. Oppenheim, A.N. (1992) Questionnaire Design, Interviewing and Attitude Measurement, London: Pinter Publishers.

22. Papanastasiou, C. \& Papanastasiou, E. (1997) "Factors that Influence Students to Become Teachers", Educational Research and Evaluation, 3, 4 pp. 305-316.

23. Papanastasiou, C. \& Papanastasiou, E. (1998) "What Factors Influences Students to Choose the Elementary Education Major," The Case of Cyprus, Mediterranean Journal of Educational Studies 3, 1 pp. 35-45.

24. Revised National Policy on Education, April 1994, Republic of Botswana.

25. Reid, 1. \& Caudwell, J. (1997) "Why did PGCE Students Choose Teaching as a Career"? Research in Education, University of Manchester, 57-58pp.47-58.

26. Rosier, M. J (1997) "Survey Research Methods" in Keeves J (Eds) Educational Research, Methodology, and Measurement: An International Handbook, Second Edition. Pergamon, Cambridge: University Press.

27. Sapsford, R (1999) Survey Research, London: Sage.

28. Serow, R.C. (1993) Why teach? Altruism and Career Choice among non- traditional recruits to teaching. Journal of research and Development 26, 4 pp. 197-204 24.

29. Sproull, N.L. (1995): Select the Research Design, Handbook of Research Methods. A Guide for Practitioners and Students in Social Sciences: Second Edition: The Scarecrow Press, Inc.

30. Tabulawa, R (I 997) " Pedagogical classroom practice and social context: the case of Botswana", International Journal of Educational Development, 17.2 pp. 189- 204.

31. Tuah, A B. (1995): A study of perceptions of the Role of Primary School Supervisors in Sarawak with Particular Reference to the Implementations of KBSR Dissertation for E D Degree, University of Bristol Graduate School of Education.

32. Yong, B.C.S (1995) "Teacher trainees' motives for entering into a teaching in Brunei Darussalain", Teaching and Teacher Education 11, 3, pp. 275-280.

33. Weinberg, E. (1983 "Data Collection: Planning and Management, in Ross, H (Eds) Handbook of Survey Research, London: Academic Press, Inc.

34. Woolfolk, A. (1993) Educational Psychology, Fifth Edition. London: Allyn and Bacon. 
Notes 